\title{
Compatibility of Fungicides on Sporulation and Growth of Trichoderma viride with Treated Seeds
}

\author{
S. Karpagavalli ${ }^{* *}$ and Nannapaneni Kiran Kumar ${ }^{1,2}$ \\ ${ }^{1}$ Department of Plant Pathology, Adhiparasakthi Agricultural College, \\ G.B. Nagar, Kalavai - 632 506, India \\ ${ }^{2}$ Department of Plant Pathology, Acharya N.G. Ranga Agricultural University, Agricultural \\ College, Bapatla- 522 101, India \\ *Corresponding author
}

\section{A B S T R A C T}

\begin{tabular}{|l|}
\hline Key w o r d s \\
Trichoderma viride, \\
$\begin{array}{l}\text { Sporulation, } \\
\text { Growth, Seeds, } \\
\text { Fungicides and } \\
\text { Sodium } \\
\text { hypochlorite }\end{array}$ \\
\hline Article Info \\
\hline $\begin{array}{l}\text { Accepted: } \\
\text { 07 August } 2020 \\
\text { Available Online: } \\
\text { 10 September } 2020\end{array}$ \\
\hline
\end{tabular}

Trichoderma spp. are tolerant and compatible with fungicides, biofertilizers and other bio pesticides. Integrating fungicide resistant antagonists with suitable fungicide treatment has importance in the frame work of integrated disease management. Incorporation of natural products provides a viable solution to the environmental problems caused by synthetic pesticides. Identification of these compounds and their further testing may be an effective approach to minimize the use of hazardous chemicals. With the above mentioned points the present research work was conducted to assess the sporulation and growth of native isolate of Trichoderma viride on fungicide treated seeds. The research work was carried out by isolation and identification of native isolate of $T$. viride, sporulation of $T$. viride on fungicide amended medium and growth of $T$. viride on fungicide treated seeds. Various fungicides viz., carbendazim $(0.1,0.2$ and 0.3 per cent), copper oxy chloride $(0.2,0.3$ and 0.4 per cent $)$, thiophanate methyl $(0.05,0.1$ and 0.2 per cent $)$, benomyl $(0.05,0.1$ and 0.2 per cent) and sodium hypochlorite $(5,10$ and 15 per cent) were used in this experiment. Sporulation of T.viride was observed in all fungicides except in thiophanate methyl and sodium hypochlorite at higher concentrations. Copper oxychloride showed the highest sporulation of $185 \times 10^{5}$ spores / $\mathrm{ml}$ and benomyl recorded $35 \times 10^{5}$ spores $/ \mathrm{ml}$ as least. Mycelial growth of $T$. viride was measured as $2.37 \mathrm{~mm}$ in sodium hypochlorite and 2.27 $\mathrm{mm}$ in copper oxy chloride treated seeds around the Colletotrichum capsici infected seeds as against $3.50 \mathrm{~mm}$ in control.

\section{Introduction}

Development of effective disease management programme requires the compatibility of potential bio agents with commonly used fungicides. Combination of chemicals and compatible bio agents is an
IDM strategy to protect the seeds and seedlings from soil and seed borne fungi (Dubey and Patil, 2001). Combining antagonists with synthetic and non- synthetic chemicals eliminates the chance of resistance development and reduces the fungicide application (Ashwani Tapwal et al., 2012). In 
recent years, both in developed and developing countries the use of hazardous fungicides for controlling plant diseases proven to cause adverse environmental effects and results in health hazards to human as well as other organisms including beneficial and natural enemies. Natural control of several phytopathogens was observed based on the presence of suppressive soils where several biocontrol microorganisms were detected such as Trichoderma, Pseudomonas and Bacillus (Huang et al., 2005). Integration of biocontrol agents with other control practice might be effective and provide acceptable levels of disease control with reduced level of chemicals. With the above aspects this work was carried out to study the compatible nature of commonly used fungicides with optimum, lower and higher concentrations on sporulation and growth of native isolate of T.viride.

\section{Materials and Methods}

\section{Fungicides on sporulation of T.viride}

Sporulation of $T$. viride in different concentrations of various fungicides was assessed by using haemocytometer. The fungicides viz., carbendazim (Bavistin $50 \%$ WP) $0.1,0.2$ and 0.3 per cent, copper oxy chloride (Fytolan 50\% WP) 0.2, 0.3 and 0.4 per cent, thiophanate methyl (Hexamar $70 \%$ WP) $0.05,0.1$ and 0.2 per cent, benomyl (Benofit $50 \%$ WP) 0.05, 0.1 and 0.2 per cent and sodium hypochlorite (Bleaching powder 3 $-8 \%) 5,10$ and 15 per cent) were used in this experiment. In $100 \mathrm{ml}$ of sterilized Czapek's broth in $250 \mathrm{ml}$ conical flasks, different concentrations of above fungicides were added Control flasks were maintained without fungicides.

Three replications were used for each treatment. The $9 \mathrm{~mm}$ disc of three days old culture of $T$. viride was inoculated in all flasks and incubated at room temperature for 15 days. At the end of incubation period, the contents were mixed thoroughly to dislodge the spores. After through shaking a drop of the filtrate was placed in a haemocytometer and the number of spores per unit was determined under microscope as per the procedure to count the cells or spores by using haemocytometer. Calculation was made by using the formula

Average number of spores counted (Medium Square)

Cells (or) spores $/ \mathrm{ml}=$

$$
\text { Volume of fluid (ml) }
$$

The sporulation of the $T$. viride was expressed as $\mathrm{x} 10^{5}$

Fungicides and $T$. viride on seed borne pathogen - Colletotrichum capsici

Supernatant metabolites of $T$. viride were collected from Czapek's broth inoculated with T. viride by filtering with Whatman No.1 filter paper. One $\mathrm{ml}$ of the $T$. viride metabolite was poured in to sterilized Petri plate and then with Czapek's medium. After solidification of the medium, various fungicides treated seeds of chillies were placed individually at the rate of 25 seeds per plate after shade drying. Chillies seeds were collected from Colletotrichum capsici infected fruits. For each concentration of different fungicides viz., carbendazim (Bavistin 50\% WP) 0.1, 0.2 and 0.3 per cent, copper oxy chloride (Fytolan $50 \%$ WP) $0.2,0.3$ and 0.4 per cent, thiophanate methyl (Hexamar $70 \%$ WP) $0.05,0.1$ and 0.2 per cent, benomyl (Benofit $50 \%$ WP) $0.05,0.1$ and 0.2 per cent and sodium hypochlorite (Bleaching powder $3-8$ $\%) 5,10$ and 15 per cent, three replications were maintained. In control plates seeds were not treated with fungicides. Plates were incubated at room temperature $\left(30 \pm 2^{\circ} \mathrm{C}\right)$ and observed the growth of $T$. viride around the seeds by compared with control plates. 


\section{Statistical analysis}

Data of the experiments were analysed by Completely Randomized Block Design (CRD) using data entry module for Ag Res Statistical Software $(0) 1994$ Pascal International Software Solutions, version 3.01 for data entry and version 7.01 for analysis.

\section{Results and Discussion}

Sporulation of $T$. viride and its growth on fungicides treated seeds on the basis of compatibility was studied in this research work. The native isolate of $T$. viride was tested against various fungicides with different concentrations under in vitro condition. Fungicides were used as lower, actual and higher concentrations for tolerance effect of $T$. viride sporulation and its growth on treated seeds.

\section{Sporulation of T.viride on different fungicides}

Experiment was conducted to study the influence of fungicides on sporulation of $T$. viride and the results were summarized in Table 1. Sporulation was observed in all fungicides and lower concentration of sodium hypochlorite except the higher concentrations of thiophanate methyl $(0.20$ per cent $)$ and sodium hypochlorite (10.00 and 15.00 per cent). Drastic reduction of spores was observed in increasing concentrations of each fungicide.

Table.1 Effect of different fungicides on sporulation of Trichoderma viride

\begin{tabular}{|c|c|c|c|}
\hline S.No. & Fungicides & Concentration (\%) & Sporulation $\left(\mathrm{x}^{2} 0^{5)}\right.$ \\
\hline \multirow[t]{3}{*}{1.} & \multirow{3}{*}{ Carbendazim } & 0.10 & $155 \mathrm{~d}$ \\
\hline & & 0.20 & $148 \mathrm{e}$ \\
\hline & & 0.30 & $143 \mathrm{~g}$ \\
\hline \multirow[t]{3}{*}{2.} & \multirow{3}{*}{ Copper oxy chloride } & 0.20 & $185 \mathrm{~b}$ \\
\hline & & 0.30 & $183 \mathrm{c}$ \\
\hline & & 0.40 & $143 \mathrm{~g}$ \\
\hline \multirow[t]{3}{*}{3.} & \multirow[t]{3}{*}{ Thiophanate methyl } & 0.05 & $138 \mathrm{~h}$ \\
\hline & & 0.10 & $95 \mathrm{k}$ \\
\hline & & 0.20 & - \\
\hline \multirow[t]{3}{*}{4.} & \multirow[t]{3}{*}{ Benomyl } & 0.05 & $145 \mathrm{f}$ \\
\hline & & 0.10 & $125 j$ \\
\hline & & 0.20 & 351 \\
\hline \multirow[t]{3}{*}{5.} & \multirow[t]{3}{*}{ Sodium hypochlorite } & 5.00 & $135 \mathrm{i}$ \\
\hline & & 10.00 & - \\
\hline & & 15.00 & - \\
\hline 6. & Control & - & $233 \mathrm{a}$ \\
\hline
\end{tabular}


Table.2 Growth of Trichoderma viride in fungicide treated seeds

\begin{tabular}{|c|c|c|c|}
\hline S.No. & Fungicides & Concentration (\%) & $\begin{array}{c}\text { Growth of } T \text {. viride } \\
(\mathrm{mm})\end{array}$ \\
\hline \multirow[t]{3}{*}{1.} & \multirow{3}{*}{ Carbendazim } & 0.10 & 2.05 cdef \\
\hline & & 0.20 & $2.03 \mathrm{cdef}$ \\
\hline & & 0.30 & $1.18 \mathrm{~h}$ \\
\hline \multirow[t]{3}{*}{2.} & \multirow[t]{3}{*}{ Copper oxy chloride } & 0.20 & $2.27 \mathrm{bc}$ \\
\hline & & 0.30 & $2.09 \mathrm{bc}$ \\
\hline & & 0.40 & $1.88 \mathrm{ef}$ \\
\hline \multirow[t]{3}{*}{3.} & \multirow[t]{3}{*}{ Thiophanate methyl } & 0.05 & $1.89 \mathrm{ef}$ \\
\hline & & 0.10 & $1.83 \mathrm{ef}$ \\
\hline & & 0.20 & $1.79 \mathrm{fg}$ \\
\hline \multirow[t]{3}{*}{4.} & \multirow[t]{3}{*}{ Benomyl } & 0.05 & $1.98 \mathrm{def}$ \\
\hline & & 0.10 & $1.54 \mathrm{~g}$ \\
\hline & & 0.20 & $0.68 \mathrm{i}$ \\
\hline \multirow[t]{3}{*}{5.} & \multirow[t]{3}{*}{ Sodium hypochlorite } & 5.00 & $2.37 \mathrm{~b}$ \\
\hline & & 10.00 & $2.21 \mathrm{bcd}$ \\
\hline & & 15.00 & $1.51 \mathrm{~g}$ \\
\hline 6. & Control & - & $3.50 \mathrm{a}$ \\
\hline
\end{tabular}

S.E. $=0.14 \quad$ C.D. $(0.05)=0.28$

Among the fungicides, copper oxychloride showed the highest sporulation of $185 \times 10^{5}$ spores / ml. Benomyl at 0.20 per cent concentration had the least of $35 \times 10^{5}$ spores $/ \mathrm{ml}$.

These results were in accordance with the report of Shukla (2011) that $T$. viride with fungicides, fytolan showed the highest sporulation and bavistin completely inhibited the sporulation. These results also showed the same trend of highest sporulation in copper oxychloride and least at benomyl. Mc Lean et al., (2001) suggested that in many fungicidal treatment there was an initial decline in Trichoderma colony forming unit counts and then gradual recovery over time. It is possible that the fungicides reduced the germination capability of the initial spore inoculum but subsequently, the germinated spores established and sporulated in the soil to bring the cfu counts back up to $10^{4}-10^{5} \mathrm{~g} /$ soil.

\section{Growth of $T$. viride in fungicide treated seeds}

In this experiment the growth of $T$. viride around the fungicide treated seeds were observed and the results were given in Table 2. Fungicide treated seeds placed on the $T$. viride amended medium showed significant differences among the fungicides compared to control.

Radial growth of $T$. viride was measured around the seeds of control showed the maximum of $3.50 \mathrm{~mm}$ followed by $2.37 \mathrm{~mm}$ in sodium hypochlorite, $2.27 \mathrm{~mm}$ in copper oxy chloride and $2.05 \mathrm{~mm}$ in carbendazim.

In all the fungicides there was no significant difference in growth among the concentrations of each fungicide. Benomyl treated seeds showed higher inhibition of $T$. viride growth $(0.68 \mathrm{~mm}$ at 0.20 per cent $)$ 
Results of this study contradictory with Mc Lean et al., (2001). They reported that $T$. harzianum C52 strain applied at planting with captan and/ or benomyl treated onion seeds provided the control of other seedling diseases.

In conclusion the sporulation of $T$. viride was observed in all the fungicides except the higher concentrations of thiophanate methyl and sodium hypochlorite in which no spores were formed. Highest sporulation was of $T$. viride were obtained in copper oxy chloride and least in benomyl. Radial growth of $T$. viride was measured around the fungicide treated and untreated seeds. Maximum growth was measured around control (untreated seeds) followed by sodium hypochlorite and copper oxychloride. All the fungicides and $T$. viride inhibited the conidia of Colletotrichum capsic $i$ in the infected seeds and then $T$. viride overgrew around the chillies seeds. Seed borne Colletotrichum capsici in chillies was inhibited by fungicides and $T$. viride in combination.

\section{References}

Ashwani Tapwal., Rajesh Kumar., Nandini
Gautam and Shailesh Pandey, 2012. Compatibility of Trichoderma viride for selected fungicides and botanicals. International Journal of Plant Pathology, 3 (2): 89 - 94.

Dubey, S.C. and Patel, B. 2001. Determination of tolerance in Thanetophorus cucumeris, Trichoderma viride, Gliocladium virens and Rhizobium sp. to fungicides. Indian Phytopathology, 54: 98 - 101.

Huang, C.J., Wang, T.K., Chung, S.C. and Chen, C.Y. 2005. Identification of an antifungal chitinase from a potential biocontrol agent, Bacillus cereus 28.9. J. Biochem. Mol. Biol. 38: 82 - 88 .

Mc Lean, K.L., Hunt, J. and Stewart, A. 2001. Compatibility of the biocontrol agent Trichoderma harzianum C52 with selected fungicides. New Zealand Plant Protection, 54: 84 - 88 .

Shukla, H.S. 2011. Compatibility of Trichoderma viride with botanicals and synthetic pesticide, insecticide and fungicide. Asian Journal of Chemical and Environmental Research, 4 (2): 6263.

\section{How to cite this article:}

Karpagavalli, S. and Nannapaneni Kiran Kumar. 2020. Compatibility of Fungicides on Sporulation and Growth of Trichoderma viride with Treated Seeds. Int.J.Curr.Microbiol.App.Sci. 9(09): 712-716. doi: https://doi.org/10.20546/ijcmas.2020.909.090 